\section{World Health Organization calls for food safety and pre- vention of food-borne illnesses}

\author{
Saurabh R. Shrivastava, \\ Prateek S. Shrivastava, \\ Jegadeesh Ramasamy
}

Department of Community Medicine, Shri Sathya Sai Medical College and Research Institute, Kancheepuram, India

\section{Introduction}

Globally, food plays a crucial role in ensuring human survival and promotion of optimal health. ${ }^{1}$ In fact, owing to the consumption of unsafe food, millions of people fall sick and many die. Thus, the World Health Organization (WHO) in the year 2000 adopted a resolution to acknowledge food safety as a public health priority. ${ }^{1,2}$ Further, WHO, in collaboration with the Food and Agriculture Organization (FA0), monitors the functions of Codex Alimentarius Commission (which formulates international standards for food safety) and of the International Food Safety Authorities Network (which provides timely information during food safety emergencies and assists nations in preventing similar incidents), ${ }^{2,3}$ In addition, WHO has also developed a Global Food-borne Infections Network to promote laboratorybased surveillance and encourage multi-sectoral collaboration. ${ }^{2}$

\section{A public health concern: food safety}

The supply and consumption of safe food plays a significant role in not only maintaining health standards of the population but even in supporting the process of continuous development of the nations through supporting the national economy via encouraging trade and tourism activities. ${ }^{1,4}$ This is primarily because of the globalization and increasing population due to which the demand for a wide range of food items has increased eventually resulting in an increasingly complex and longer global food chain. ${ }^{1,5,6}$ Furthermore, over a period of time due to the urbanization, changes in consumers' habits and increase in travel, a greater number of people is buying and consuming food items which are prepared in public places. ${ }^{1,5}$

Definitive evidence is available to suggest that consumption of unsafe food can propagate the vicious cycle of diarrhoea-malnutrition- diarrhoea, which can significantly affect the nutritional status of the population. ${ }^{4}$ It is very important to understand that although food contamination can occur at any level of food chain, the majority of the food-borne illnesses precipitate owing to the improper preparation/handling of the food items. ${ }^{4,5}$ In fact, results of the various epidemiological studies have concluded that a massive gap exists in the knowledge and practice of food handlers working in food establishments. ${ }^{7,8}$

\section{Food-borne illnesses}

Globally, it has been identified that an excess of 200 diseases results because of consumption of contaminated food or water accounting for deaths of almost 2 million individuals on an annual basis. ${ }^{5,9} \mathrm{~A}$ large number of food-borne outbreaks has been reported across different parts of the world both in nondeveloped and developed nations, most recently being the German outbreak of Escherichia coli attributed to the consumption of contaminated fenugreek sprouts. ${ }^{10}$

\section{Identified shortcomings}

Although the policy makers and international agencies are aware of the after-effects of unsafe food, yet the stakeholders have failed to ensure food safety throughout the food chain. ${ }^{1,4}$ This has been attributed to the presence of multiple challenges, like the following.

First, increasing internationalisation and complexity of the food supply chain. Owing to the internationalization of trade/tourism and complex nature of food chain, the food contamination can occur at various different stages before it is actually consumed.

Second, emergence of resistance. Due to the misuse (under/overuse) of antimicrobials in the fields of agriculture and animal husbandry, emergence of antimicrobial resistance has been observed across the globe. The problem gets further aggravated when humans consume animal foods enabling transmission of resistant bacteria to themselves and thus compromising their health standards.

Third, absence of integration with other national policies. Even today, a major proportion of WHO member states have not prioritized integration of food safety with other programs to provide a smart solution to the problem of food-borne illnesses. In fact, even at administrative levels, varying extents of fragmentation have been observed among the food safety authorities.

Fourth, absence of multi-sectoral cooperation. In order to ensure food safety and prevent
Correspondence: Dr. Saurabh RamBihariLal Shrivastava, Department of Community Medicine, Shri Sathya Sai Medical College and Research Institute, Thiruporur-Guduvancherry main road, 603108 Kancheepuram, India.

Tel/Fax: +91.988.422.7224

E-mail: drshrishri2008@gmail.com

Contributions: SS, conception and design, drafting of the article, review of the literature, guarantor; PS, drafting of the article, review of the literature, revising the paper critically for important intellectual content; JR, general supervision of the research, overall guidance in writing the manuscript.

Conflict of interest: the authors declare no potential conflict of interest.

Key words: Food safety; Food-borne illnesses; World Health Organization.

Received for publication: 5 April 2015.

Revision received: 14 July 2015.

Accepted for publication: 18 July 2015.

This work is licensed under a Creative Commons Attribution 3.0 License (by-nc 3.0).

(C) Copyright S. R. Shrivastava et al., 2015

Licensee PAGEPress, Italy

Healthcare in Low-resource Settings 2015; 3:5217 doi:10.4081/hls.2015.5217

food-borne illnesses, it is a must that all the responsible sectors should work in an integrated manner. However, multiple lacunae and lack of coordination have been observed, which have significantly delayed the overall progress of ensuring universal food safety.

Fifth, lack of resources. In most of the settings, lack of resources (such as absence of a holistic surveillance mechanism to identify and notify cases of food-borne resources, limited financial support, minimum number of trained staffs or awareness campaigns, etc.) has also influenced the efforts of stakeholders.

Sixth, population growth. In view of the continuous rise in human population, food supply demand has progressively increased and thus serious concerns have emerged regarding food safety.

Seventh, climate changes. Due to the deterioration of the climate over the last couple of decades, the practices of food production, storage and distribution have become quite demanding..$^{1,-6,9}$

\section{Suggested measures}

Owing to the global impact of food safety and universal nature of food-borne illnesses, the need of the hour is that policy makers 
should establish appropriate food systems and infrastructures to address any food safety risks along the complete food chain; encourage coordination between multiple sectors; and adopt strategies to enable integration of food safety with other food policies. ${ }^{1,5}$ Further, all the parties involved in the food chain should adhere to their responsibility to maintain food safety. ${ }^{1,4}$ At the same time, food handlers/consumers should take efforts to get accustomed to the food they use so that they can make an informed food choice, and should handle food safely or grow fruits and vegetables all according to the recommendations made by the WHO.$^{1,4,5}$ Finally, strategies like empowering women through food safety education in Senegal or sensitizing students in school regarding safe food as evidenced in Haiti, can be implemented in various parts of the world to make food safe. ${ }^{11,12}$

\section{Support by the World Health Organization}

The World Health Organization (WHO) has called for both global prevention of food-borne illnesses, and establishment of an effective public health response to facilitate prompt detection of food-borne illnesses. ${ }^{1,5}$ In-fact, in order to show their commitment, WHO has adopted Food safety: from farm to plate, make food safe as the theme for the year 2015. ${ }^{13}$ Subsequently, the organization has devised Five keys to safer food (viz. keep clean; separate raw and cooked; cook thoroughly; keep food at safe temperatures; and use safe water and raw materials) at home/hotels/markets, and Five keys to growing safer fruits and vegetables (viz. practice good personal hygiene; protect fields from animal faecal contamination; use treated fecal waste; evaluate and manage risks from irrigation water; and keep harvest and storage equipment) for those who usually do not have access to food safety education, in order to promote health by decrease microbial contamination. ${ }^{14,15}$ By ensuring compliance with the above measures thousands of food handlers, including consumers, are empowered to prevent food-borne diseases and thus they can play an important role in safe food supply. ${ }^{14,15}$

Moreover, WHO is assisting nations to ensure the prevention, detection and appropriate management of food-borne risks in accordance with the guidelines developed by the Codex Alimentarius. ${ }^{1,5}$ However, various nations have adopted these guidelines because of the law proposed by the World Trade Organization. In fact, there is a provision that nations can even adopt other standards provided they can justify these differences by means of a risk assessment. In addition, WHO has played a remarkable role in evaluating the safety of newer technologies employed in food production, in strengthening the national food systems and legal framework, and in obtaining the precise estimate of the global burden of food-borne diseases. ${ }^{1,5}$

\section{Conclusions}

To conclude, owing to the complex nature of food supply chain, it is high time that all the concerned stakeholders should work in coordination as proposed by the World Health Organization to ensure global food safety and thus prevent cases of food-borne illnesses.

\section{References}

1. Chan M. Food safety must accompany food and nutrition security. Lancet 2014;384:1910-1.

2. Fukuda K. Food safety in a globalized world. B World Health Organ 2015;93:212.

3. World Health Organization. INFOSAN in action in the Americas; 2014. Available from: http://www.who.int/foodsafety/areas 0_work/infosan/en/\#story-02

4. World Health Organization. 10 facts on food safety; 2015. Available from: http://who.int/features/factfiles/food_safety/en/
5. World Health Organization. Food safety Fact sheet $\mathrm{N}^{\circ} 399 ; 2014$. Available from: http:/who.int/mediacentre/factsheets/fs39 9/en/

6. Anderson J, Bogart N, Clarke A, et al. Food safety management in the global food supply chain. Perspect Public Heal 2014;134:181.

7. Brown LG, Le B, Wong MR, et al. Restaurant manager and worker food safety certification and knowledge. Foodborne Pathog Dis 2014;11:835-43.

8. Bobhate PS, R Shrivastava S, Gupta P. Profile of catering staff at a tertiary care hospital in Mumbai. Australas Med J 2011;4:148-54.

9. World Health Organization. How safe is your food? 2015. Available from: http://who.int/campaigns/world-healthday/2015/en/

10. Biliński P, Kapka-Skrzypczak L, Posobkiewicz M, et al. Public health hazards in Poland posed by foodstuffs contaminated with E. coli 0104:H4 bacterium from the recent European outbreak. Ann Agr Env Med 2012;19:3-10.

11. World Health Organization. Empowering women through food safety education; 2015. Available from: http://who.int/foodsafety/areas_work/food-hygiene/empowered-women/en/

12. World Health Organization. Haiti: safe food in rural schools; 2015. Available from: http://www.who.int/features/2015/haitifood-safety/en/

13. World Health Organization. World Health Day 2015: Food Safety; 2015. Available from: http://who.int/foodsafety/en/\#story02

14. World Health Organization. Food safety. The five keys to safer food programme; 2015. Available from: http://who.int/foodsafety/areas_work/food-hygiene/5keys/en/

15. World Health Organization. Five keys to growing safer fruits and vegetables: promoting health by decreasing microbial contamination. Geneva: WHO press; 2012. 